\title{
A Comparative Analysis of Customers' Satisfaction for Conventional and Islamic Insurance Companies in Pakistan
}

\author{
Pervez Zamurrad Janjua ${ }^{1}$ \& Muhammad Akmal ${ }^{1}$ \\ ${ }^{1}$ School of Economics, International Islamic University, Islamabad, Pakistan \\ Correspondence: Pervez Zamurrad Janjua, School of Economics, International Islamic University, Islamabad, \\ Pakistan. Tel: 51-925-8038. E-mail: dr.pervezzamurrad@iiu.edu.pk
}

Received: October 17, 2013

Accepted: January 22, 2014

Online Published: March 25, 2014

doi:10.5539/ijef.v6n4p36

URL: http://dx.doi.org/10.5539/ijef.v6n4p36

\begin{abstract}
Islamic finance and insurance are penetrating in international markets especially after world economic crisis since 2008. This research is an attempt to analyze customers' satisfaction for the services of conventional and Islamic insurance companies in Pakistan. A modified SERVQUAL model is used to measure the service quality in the constructs of reliability, responsiveness, empathy, convenience and Sharīa ${ }^{\prime} h$ compliance. For this purpose primary data of 400 customers, 173 from conventional and 227 from Islamic insurance companies, is estimated through propensity score matching as well as linear, non-linear and non-parametric classification techniques. The results on service quality indicate significant gap between expectation and perception of overall insurance industry. No significant difference of service quality is found between conventional and Islamic insurance companies in the constructs of reliability, responsiveness, convenience and empathy. The findings suggest a significant improvement in the service quality of conventional and Islamic insurance industry. Particularly, the conventional insurance companies need to focus on young people, private employees and lower income groups, whereas the Islamic insurance companies have to put more efforts to improve Sharì ${ }^{-} a h$ compliance and to attract self-employed and higher income groups.
\end{abstract}

Keywords: SERVQUAL model, customer satisfaction, service perception, service expectation, Islamic insurance, insurance sector of Pakistan

\section{Introduction}

Customers' satisfaction and service quality are certainly the two fundamental concepts that are at the core of marketing theory (Spreng \& Mackoy, 1996). In current scenario of intense competition, delivery of high quality of services is the key of sustainable competitive advantage which results in satisfied customers (Shemwell et al., 1998). Risk and return are positively associated with each. But everyone wants to maximize return with minimum or no risk. Risk can be managed through better management including insurance.

In the past insurance industry has not much pressure from customers' side. Probably, the insurance customers were not much aware of insurance operations. However, the situation has been changed now and insurance industry is facing pressure from customers' demand. Customers of insurance sector are now more knowledgeable. Consumers have eight rights as declared by the International Consumers Movement, namely right to satisfaction, choose, information, basic goods and services, education, reparation and safe and clean environment (Sungip \& Affiaine, 2008).

Customer satisfaction is considered as essential for customer retention and loyalty, and clearly it helps in grasping economic objectives, such as profitability, market share and return on investment (Sungip \& Affiaine, 2008). Customer satisfaction leads to the growth of fianancial sector and growth of financial sector leads to the growth of economic sector of a country (Shahid et al., 2010). For the growth of any industry customer satisfaction is very important. To increase the customer satisfaction we need to know the existing level of customer satisfaction and the structure of operationalization which leads to such satisfaction (Hamid, 2011).

The financial sector of Pakistan is comprised of Islamic banks, commercial banks, investment banks, stock exchange, conventional and Islamic insurance (Takäful) companies. Security and Exchange Commision of Pakistan (SECP) is the regulator of insurance industry in Pakistan. Currently, 50 insurance companies are working in Pakistan, out of which five are Islamic insurance companies (SECP, 2013). Assets of insurance 
industry were 386 and 501.8 billion rupee for the years 2009 and 2011, respectively (Government of Pakistan, 2009, $2010 \& 2011)$.

Insurance industry of Pakistan is small as compared to other regional emerging economies, yet it has vast potential for growth. In 2010 growth in real premium was $11 \%$ in emerging economies, world average was $2.7 \%$ and in Pakistan it was 2.6\% (State Bank of Pakistan, 2011). Penetration of insurance sector in Pakistan is also very low in international perspective, which indicates that insurance companies are not fully utilizing their potential (State Bank of Pakistan, 2011).

A few studies have been done on banking sector of Pakistan for checking the service quality (for instance Naeem et al., 2009; Ahmad et al., 2010; Khalid et al., 2011). According to best of our knowledge no study has been done to compare the service quality of Islamic insurance as well as conventional insurance in the context of Pakistan. Thus, the basic objective of this study is to analyze customer satisfaction on the basis of service quality for conventional and Islamic insurance industry. The specific research questions are as under:

- What are the demographic characteristics of the respondents and does the level of customer satisfaction of conventional and Islamic insurance companies depend on these demographic characteristics?

- What is the level of customer satisfaction in terms of service quality of conventional and Islamic insurance companies?

- How far the preferences of customers of conventional and Islamic insurance companies differ from each other?

The study will provide recommendations to policy makers and practitioners to enhance customer's satisfaction in terms of certain aspects in order to increase the level of service quality for future growth of insurance industry in Pakistan.

\section{Conventional Versus Islamic Insurance}

Apparently both conventional and Islamic insurance contract look similar but there are some factors in conventional insurance contradictory to Islamic law (Sharīah) including uncertainty of price and delivery of product (Gharar), gambling (Maysir), interest (Ribā), violation of Islamic law of inheritance (Mĩrath) and unlawful appropriation of others' property (Akûl-ûl-Māl-Bil-Batil). First factor is 'uncertainty' (Gharar). In conventional insurance uncertainty of payment is accepted as agreed in the contract and the amount as well as the time of payment is not defined in case of mishap. Second factor is gambling (Maysir). Participants contribute small sums in hope of gaining larger sums. Premiums paid by the participants are lost, when events do not occur. If claims are more than premiums in value then the insurance company is in shortfall. Third factor is interest $(R i b \bar{a})$. It results when earnings of insurance company are paid to the insured on claims (Lian \& Aziz, 2006). Interest accrues to the insured when the indemnity is more than the premium and to the insurer when indemnity is less than the premium. Fourth factor is the violation of Islamic law of inheritance (Mirath). In conventional insurance the compensation is given to the nominees and not to the legal heirs. Fifth factor is unlawful appropriation of others' property (Akûl-âl-Mäl-Bil-Batil). If no loss occurs, then all premiums are kept by the insurer in general insurance contract.

Islamic insurance (Takāful) is being practiced on the basis of profit and loss sharing (Mudārabah), principal-agent contract (Wakālah) and endowment fund sum principal-agent contract (Waqf-Wakālah) (Note 1). The last model is commonly used by different Islamic insurance companies in Pakistan. The basic purpose of this fund is to provide support to participants in case of certain losses according to the rules of the Waqf fund (Wahab et al., 2007).

In this model at first endowment fund (Waqf) is created by the investors. Participants contribute to the endowment fund. Insurance operator acts as an agent of the endowment. Operator makes investments of endowment fund and shareholders capital on profit and loss (Mudārabah) basis. The operator takes a share in profit from investment and fee from contributions. Claims are fulfilled on the basis of donations by the endowment fund. 


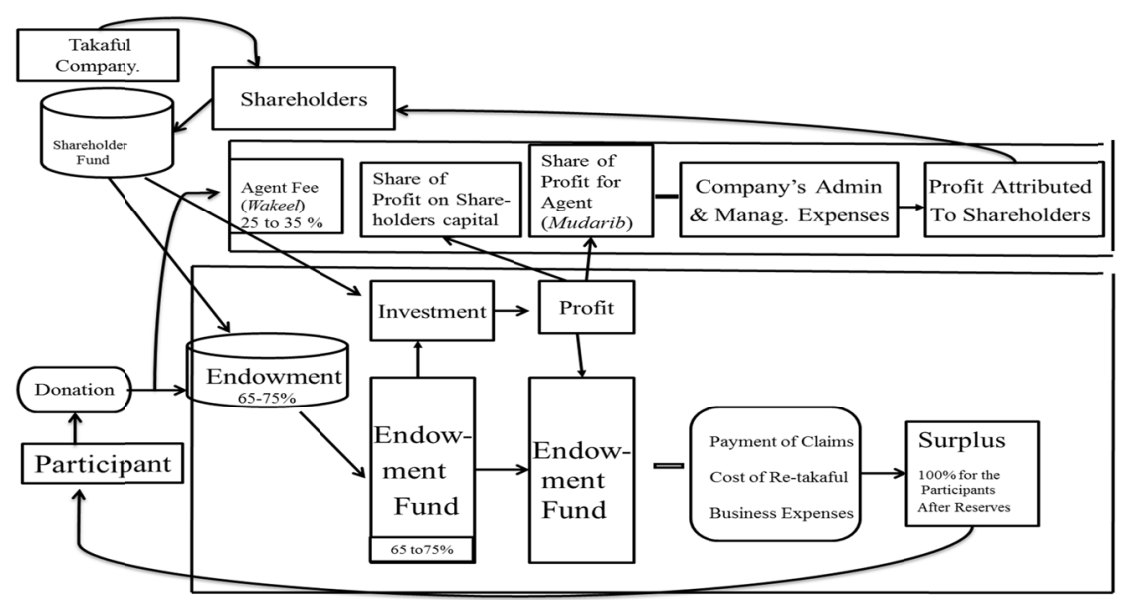

Figure 1. Waqf-Wakālah model of general Islamic insurance (Takāful)

Sources: Khan (2013); Wahab et al. (2007); Authors' own contribution.

There are some fundamental differences between conventional and Islamic insurance. These differences are summarized in Table 1.

Table 1. Conventional versus Islamic insurance

\begin{tabular}{|c|c|c|}
\hline Criteria & Conventional Insurance & Islamic Insurance (Takāful) \\
\hline Nature of Contract & $\begin{array}{l}\text { It is an exchange contract, where one party is } \\
\text { seller and other is purchaser }\end{array}$ & $\begin{array}{l}\text { It is a donation contract, where the } \\
\text { policyholder make donation for a specific } \\
\text { purpose }\end{array}$ \\
\hline $\begin{array}{l}\text { Ownership of } \\
\text { Premium/Contribution }\end{array}$ & Premium belongs to company & $\begin{array}{l}\text { Contribution belongs to participants or Waqf } \\
\text { fund }\end{array}$ \\
\hline Responsibility of Company & $\begin{array}{l}\text { Pay claims from underwriting funds and } \\
\text { shareholders' equity }\end{array}$ & $\begin{array}{l}\text { Pay claims from underwriting fund and } \\
\text { interest free loans from shareholders to the } \\
\text { endowment fund in case of shortfall of funds }\end{array}$ \\
\hline $\begin{array}{l}\text { Responsibility of } \\
\text { Policyholder/Participants }\end{array}$ & Policyholders pay premiums & Policyholders pay contributions/donations \\
\hline Nature of Capital & Shareholders' capital is utilized for investment & $\begin{array}{l}\text { Shareholders' and participants' funds can be } \\
\text { utilized for investment }\end{array}$ \\
\hline Investment Considerations & $\begin{array}{l}\text { No restrictions on investment except prudential } \\
\text { limitations }\end{array}$ & Investment should be Sharīa $a h$ compliant \\
\hline Business Concerns & It can provide insurance cover to any business & It can cover only Sharī'ah compliant business \\
\hline
\end{tabular}

\section{Literature Review}

Insurance is purely a service provider industry. SERVQUAL is an instrument which is developed by Parasuraman and his colleagues to estimate the service quality as a difference between expectation \& perception of service-users. Service can be defined as the performance or act that can be offered from one party to another, its nature is essentially intangible, and no ownership is created as a result (Kotler \& Keller, 2006). Quality is difficult to define because everyone has different experience and perception regarding quality of product or service. In technical usage it can be referred to as the salience of the products in satisfying their users (Ghobadian et al., 1994). Here, the purpose is to assess the service quality that can only be measured during or after the consumption of services.

To ensure the customers' satisfaction, service quality had been up in the researchers' books. There are a good number of studies which have been carried out for checking the service quality of banking and insurance in different countries of the world (e.g., Tahir et al., 2006; Sungip, 2008; Chong et al., 2011; Upadhyaya \& Badlani, 2011; Sadeghi \& Farokhian, 2011).

Explorations have showed that service quality is being progressively accepted as an important feature in the accomplishment and achievement of any trade and industry (Parasuraman et al., 1998) and the insurance services here take no exceptional stance. As Islamic insurance companies are growing in Pakistan, competition among insurance companies turns out to be more powerful. Furthermore, customers have become more refined and hence the significance of service quality is more demanding. Thus, the insurance companies strategically have to 
consider these aspects in offering quality products to satisfy their clientele.

It is very challenging task to satisfy customers in any business; hence it is also very difficult to meet the expectation of customers in service sector. There are many studies which have been conducted to find this gap of service quality as a differential of expectation and perception by using SERVQUAL model (e.g., Tahir et al., 2006; Kumar et al., 2009; Leo, 2009; Sadeghi \& Farokhian, 2011). Safakli and Veli (2007) concluded that perceived service quality was lower than the level of expectation and a service quality gap was significant in SERVQUAL dimensions, i.e., expectations were very higher than perception in banking sector of Northern Cyprus. Another study on banking sector in Pakistan revealed that customers perceived highest satisfaction in the dimensions of responsiveness and reliability. Little gap was found between expectation and perception in these dimensions of SERVQUAL (Khalid et al., 2011).

Service quality may differ between firms, i.e., one firm may offer better services than other one. Some previous studies concluded that the overall SERVQUAL gap for Islamic banks was meaningfully greater than the conventional banks (Kumar et al., 2009). Some studies used compliance (Sharìa $a h$ compatibility in business) as an additional dimension to the conventional dimensions of SERVQUAL and revealed that the compliance was significant attribute that contributed to the criteria for choosing Islamic financial institutions that offered Islamic products in the market (Othman \& Owen, 2001; Osman \& Ali, 2009).

Some studies estimated the service quality of insurance companies. One of these studies showed that there was huge gap between perception and expectation of SERVQUAL for reliability, responsiveness and empathy in Malaysian insurance industry. Reliability came up as the most important element of SERVQUAL in Malaysian insurance industry (Sungip, 2008). In another study it was revealed that service quality was found less satisfactory in reliability, responsiveness and empathy dimensions in Indian life insurance industry (Upadhyaya \& Badlani, 2011).

Checking the service quality of Islamic insurance is also an important task. For this purpose SERVQUAL is also useful instrument for gauging the service quality of insurance sector.

\section{Methodology}

\subsection{Models for Measuring Service Quality}

There are a number of models which have been used to assess service quality of firms.

Parasuraman et al. (1985) developed SERVQUAL model which is also called gap model. This model has been widely used in different types of industries such as fast food restaurant, hospitals, business schools, banking and insurance sectors (Ladhari, 2009). The model considers in first stage demographics of customers and in second stage five dimensions of service which are tangibility, reliability, assurance, empathy and responsiveness. The later stage has 22 questions for expectation and 22 for perception. Service quality is determined by analyzing the gap between expectation and perception. This model has been used by various researchers as mentioned in Table 2.

Table 2. SERVQUAL applications in previous researches (1990-2011)

\begin{tabular}{llll}
\hline Authors & Sector & Country & Year \\
\hline Carman & Business schools etc. & USA & 1990 \\
Parasuraman et al. & Telephone/insurance companies & USA & 1991 \\
Finn and Lamb & Retail stores & USA & 1991 \\
Babakus and Boller & Electricity and gas company & USA & 1992 \\
Cronin and Taylor & Banking, pest control, etc. & USA & 1992 \\
Headley and Miller & Medical services & USA & 1993 \\
Taylor and Cronin & Shopping malls & USA & 1994 \\
Kettinger and Lee & Educational institution & USA & 1994 \\
Pitt et al. & Online production systems & UK, USA & 1995 \\
Nitecki & Library services & USA & 1996 \\
Duffy et al. & Nursing home & UK, USA & 1997 \\
Lam & Patients & Hong Kong & 1997 \\
Mels et al. & Banks, insurance, etc. & South Africa & 1997 \\
Durvasula et al. & Shipping organizations & Singapore & 1999 \\
Morales Espinoza & Supermarkets customers & Canada, Peru & 1999 \\
Cook and Thompson & University libraries & USA & 2000 \\
Engelland et al. & Campus career services centers & USA & 2000 \\
Gefen & Amazon.com services & USA & 2002 \\
Kang et al. & University employees & Korea & 2002 \\
Lam & Banks customers & China & 2002 \\
Van der Wal et al. & Cellular phone users & South Africa & 2002 \\
\hline
\end{tabular}




\begin{tabular}{llll}
\hline Zhou et al. & Bank customers & China & 2002 \\
Baldwin and Sohal & Dental care services & Australia & 2003 \\
Chi Cui et al. & Banks customers & South Korea & 2003 \\
O'Neill and Palmer & Visitors to theme parks & Australia & 2003 \\
Kilbourne et al. & Nursing home residents & USA \& UK & 2004 \\
Arasli et al. & Bank customers & Greek, Cypriot & 2005 \\
Badri et al. & Information technology services & UAE & 2005 \\
Paulins, V. A & Retail stores services & USA & 2005 \\
Gounaris & Companies (B2B services) & Greece & 2005 \\
Landrum et al. & Army engineering corps & USA & 2007 \\
Ahmad \&Sungip & Malaysia insurance industry & Malaysia & 2008 \\
Mukesh Kumar et al. & Conventional banks & Malaysia. & 2009 \\
Othman \& Owen & Islamic banks & Kuwait & 2009 \\
Hossain and Leo & Retail banking & Qatar & 2009 \\
Ravichandran et al. & Banks & India & 2010 \\
Mishra et al. & Banks & India & 2010 \\
Awan et al. & Conventional and Islamic banks & Pakistan & 2011 \\
Ladhari et al. & Customer satisfaction & Tunisia, Canada & 2011 \\
Salman Khalid et al. & Banks & Pakistan & 2011 \\
Upadhyaya \& Badlani & Life insurance & India & 2011 \\
Sadeghi \& Farokhian & Insurance & Iran & 2011 \\
\hline
\end{tabular}

Cronin and Taylor (1992) developed SERVEPERF model by using five original dimensions of SERVQUAL. They were of the view that if they eliminate the dimension of 'expectation', the questionnaire would be friendlier for respondents, because it decreases the number of questions from 44 to 22 . But on other hand Parasuraman et al. (1994) argued that expectation and perception gap gives both the desired and adequate levels of service quality.

Sureshchandar et al. (2001) developed a model to check the customer satisfaction in Indian banks. In this model there are five service quality factors which are considered important for customers. First factor is core service or service product (features that are offered in a service). Second factor is human element of service delivery (reliability, assurance, empathy, responsiveness). Third factor is non-human element (the process procedure and technology). Fourth factor is tangibility of services (equipment, signage and employee appearances). Fifth factor is social responsibility (reasonable cost, equal treatment of customers etc.). There are total 41 questions on seven point Likert scale and it is only for checking the perception not for gap analysis.

Othman et al. (2001) developed CARTER model by using five original dimensions of SERVQUAL, and one additional dimension of compliance to check the Sharīah compatibility of Islamic financial institutions. Compliance dimension contains nine items. This model is basically designed for checking the customer satisfaction in Islamic financial institutions including Islamic banks and insurance companies. This model also contains two parts. First part deals with demographics of customers. In second part, by using a 5 point Likert scale anchored at "strongly agree" and "strongly disagree", respondents are asked to evaluate parameters on service quality relevant to the banking or insurance industry.

Evangelos and Rand (2006) developed GIQUAL model to check the service quality of insurance firms. It is a SERVQUAL type service-quality instrument which was developed for Greek insurance. It contains 5 dimensions (namely tangibility, empathy, assurance, reliability and responsiveness) and 25 questions. A four-section questionnaire is used in this model. First section deals with demographics. Second section consists of GIQUAL dimensions. Third section contains questions on which respondent are asked on overall satisfaction with their respective insurance firm and its services on a scale of 1 to 10. Fourth section appraises customers' emotional and behavioral loyalty levels.

Siddiqui and Sharma (2010) constructed another model to check the satisfaction of insurance customers in India. There are six dimensions in this instrument, namely personalized financial planning, assurance, competence, tangibles and technology and corporate image. These dimensions were used in a cross-sectional descriptive research design for the study of service quality structure in life insurance sector. This instrument is like a SERVQUAL questionnaire. The questionnaire is comprised of two sections. First part contains information relating to different demographic and socioeconomic criteria like age, educational qualification, profession and income. In second part, respondents are asked to assess those parameters on service quality which are relevant to insurance industry on a 5 point scale, i.e., "strongly agree" and "strongly disagree". This part consists of 26 statements regarding various aspects of service quality for both expectations and perception scores.

The models which we discussed above were developed by different researchers in different times for checking the service quality of firms. Most of the above mentioned models were used for checking the service quality of 
financial firm such as banking and insurance industry. However, SERVQUAL model has been used for other industries as well. Most of the models used format and dimensions of SERVQUAL model.

SERVQUAL model is used by most of the empirical studies from 1990 to 2011 for different types of industries as mentioned in Table 2. This model is more suitable for our research on following points:

1. It has been a host of many previous researches that reflects the level of confidence of researchers on this model to evaluate service quality.

2. Its application is universal. That is to say, it can be applied on any service industry in any form of cultural context.

3. All other models, as discussed above, are basically the subsets of SERVQUAL, with little modifications.

Thus, the model we used in this study for checking the service quality of Islamic and conventional insurance firms is based on SERVQUAL model. Although in this study SERVQUAL model is not fully adopted but the basic idea of gap analysis is taken from this model and some constructs of this model have also been used in current study.

Basic structure of our modified SERVQUAL model is given below:

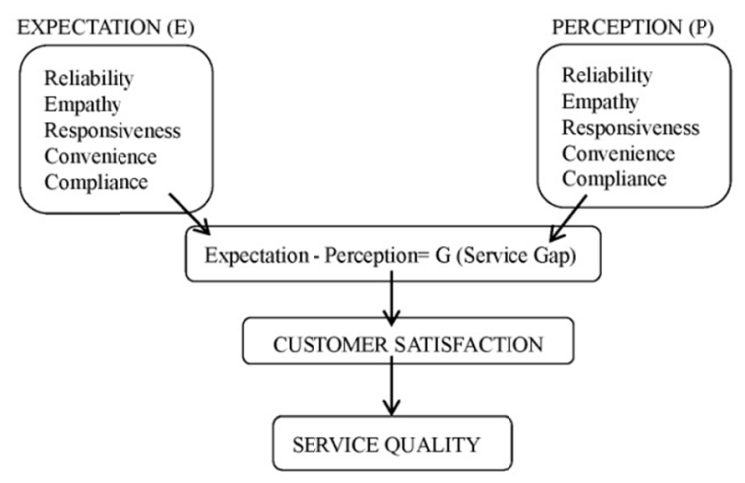

Figure 2. Modified SERVQUAL model

\subsection{Service Quality Variables}

Selection of various constructs for service quality is not an easy task. An industry varies according to its nature of business, thus questionnaire is needed to be tailored according to the nature of business to cope with all its aspects. In this research, as discussed above, base model is SERVQUAL (Parasuraman et al., 1985). The model is constructed to measure the gap between expectation and perception. For this study the model is little modified according to the requirement of insurance industry and cultural environment in Pakistan. We did not consider the constructs of tangibility and assurance because the former may not be so effective in an under-developed market with relatively low level of competition and the later is partially overlapping with the construct of reliability. Thus, in context of expectation and perception of customers, the aspects of responsiveness, reliability and empathy (Parasuraman et al., 1994; Şafakli \& Veli, 2007) as well as two additional dimensions, namely 'convenience' and 'compliance' are used. The variable of convenience is used in this study because of its importance for the satisfaction of customers. This variable has already been used by many researchers (e.g., Kumar et al., 2009; Siddiqui et al., 2010; Sharma et al., 2011; Taap et al., 2011). Moreover, as this study compares conventional and Islamic insurance companies, therefore compliance of the business with Islamic law (Sharíah) appears to be very relevant to assess the level of satisfaction among customers. The variable of compliance has been used in some other studies on banking industry (e.g., Shafie et al., 2011; Slamet et al., 2007; Osman \& Ali, 2009; Ramdhani et al., 2011).

In short, responsiveness is the readiness at the end of insurance company to help its customers and provide quick service. Reliability relates to the company's ability to perform the promised service dependably and perfectly. Convenience is the ease of using services and empathy is the provision of attention and care by the company to its customers. Compliance means adoption of Sharía ${ }^{\prime} h$ rules in business operations.

Preference is another construct which is included in this research. There are six questions in this construct. This variable is included in this study after making a detail discussion with researchers and practitioners. The aim of 
including this variable is to know the purpose of choosing specific insurance company and specific insurance policy by the respondents. If the insurance providers know the preferences of the clients then they would be in a better situation to tailor the products according to the needs of clients.

\subsection{Data}

Data collection on micro level in developing economies is a very difficult task. There are 50 registered conventional and Islamic insurance companies working in Pakistan (SECP, 2013). The population of this study includes general insurance and life insurance companies operating in Pakistan. The study period is 2012.

For data collection, a questionnaire was devised to ensure that all relevant information required for analysis could be acquired. Four hundred valid responses were collected, two hundred and twenty three responses from Islamic and rest from conventional insurance sector. Data was collected through self-administrated, pre-structured questionnaire, consisted of four parts. First part related to demographics of customers. Second part consisted questions about policyholders' expectation on the service delivered by the relevant insurance companies. Expectations were acquired on the 24 service attributes. Third part checked the perception of customers consisted of 24 service attributes. Fourth section included the preferences of respondents for choosing the specific insurance firm and it was consisted of seven attributes on four points interval scale. For making the sample more representative of population, we used random sampling from the customers of the relevant insurance companies. In this study most of the sample was taken from Rawalpindi and Islamabad area due to time and financial constraints and because the people in twin-cities have access to all kinds of insurance channels and thus can be considered as the representative of the target population for the assessment of insurance service quality in Pakistan. For the convenience of the respondents, we translated the questionnaire in Urdu and also created online questionnaire.

\section{Results and Discussion}

In this section first we analyze the demographics of the respondents. Then we check service quality of the insurance industry. After that we do comparative analysis of customer satisfaction. Lastly, preferences of customers are analyzed to derive suitable policy guide.

\subsection{Analysis of the Demographics of Respondents}

In this section analysis is made for each variable of demographic characteristics of respondents. Results are given in Table 3.

Table 3. Demographics of the respondents

\begin{tabular}{|c|c|c|c|c|c|}
\hline \multicolumn{3}{|c|}{ Insurance Category } & \multicolumn{3}{|c|}{ Education Level } \\
\hline Category & Frequency & Percent & Education & Frequency & Percent \\
\hline Motor Vehicle & 112 & 28 & Below High School & 2 & 1 \\
\hline Fire \& Property & 27 & 7 & High School & 13 & 3 \\
\hline Engineering & 13 & 3 & Higher Secondary School & 56 & 14 \\
\hline Travel & 9 & 2 & Bachelor & 97 & 24 \\
\hline Health & 36 & 9 & Master & 169 & 42 \\
\hline Group Life & 31 & 8 & Above Master & 63 & 16 \\
\hline Individual Life & 163 & 41 & Total & 400 & 100 \\
\hline Others & 9 & 2 & & & \\
\hline \multirow[t]{2}{*}{ Total } & 400 & 100 & & & \\
\hline & Type of Education & & \multicolumn{3}{|c|}{ Age } \\
\hline Type & Frequency & Percent & Age* & Frequency & Percent \\
\hline Finance/Business & 185 & 46 & $18-25$ & 110 & 27 \\
\hline Medical & 18 & 5 & $26-35$ & 130 & 32 \\
\hline Engineering & 34 & 8 & $36-50$ & 145 & 36 \\
\hline Arts & 138 & 34 & $50-60$ & 11 & 3 \\
\hline Others & 25 & 6 & $61 \&$ Above & 5 & 1 \\
\hline \multirow[t]{2}{*}{ Total } & 400 & 100 & Total & 400 & 100 \\
\hline & Profession & & Inc & ne Range & \\
\hline Profession & Frequency & Percent & Income* & Frequency & Percent \\
\hline Student & 74 & 18 & $5-15$ & 48 & 12 \\
\hline Private Employee & 208 & 52 & $16-25$ & 68 & 17 \\
\hline Govt. Employee & 45 & 11 & $26-35$ & 82 & 20 \\
\hline Self Employed & 67 & 17 & $36-45$ & 84 & 21 \\
\hline Others & 7 & 2 & $46-55$ & 50 & 13 \\
\hline \multirow[t]{2}{*}{ Total } & 400 & 100 & $56 \&$ Above & 68 & 17 \\
\hline & & & Total & 400 & 100 \\
\hline
\end{tabular}

*Age in years and income in thousands Rupee per month. 
Being a male dominated society in Pakistan, less than five percent of the respondents belong to female group.

First variable is insurance category. Results of frequency analysis show that most of the respondents have individual life insurance and motor vehicle policy having a share of 41 and 28 percent, respectively. On third place the respondents have health policy $(9 \%)$.

Second category is educational level of respondents. The statistics reflect that $2 / 3$ of all respondents are graduates and only $3 \%$ of the respondents have finished high school.

Third category is type of education. $46 \%$ of the policy holders have business and financial type of education and $34 \%$ have arts education. Thus, we may conclude that the frequency of taking insurance policy is more among those persons who have knowledge in business and finance.

Now, we consider the frequency as per age of the respondents. The results of this category show that more than $2 / 3$ of all respondents $(68 \%)$ have age between $26-50$ years. It means majority of the respondents belongs to active age. More than 1/4 of all respondents belong to young policyholders having age between 18-25 years.

The frequency was also checked in context of profession of respondents. $52 \%$ of the respondents are by profession private employees. Second and third dominant categories are students and self-employed. Thus, we can conclude that private employees are more interested to have an insurance policy than government employees.

Lastly, we tested the frequency of respondents in relation with level of income. Most of the respondents' income level is $36-45$ thousands rupees, their percentage is 21 . The second largest category belongs to the income level of 26-35 thousand rupee, which is 20 percent of overall respondents. $16.8 \%$ of the respondents have income range of 16-25 thousand rupee. Thus, more than half of the respondents belong to middle income group having income range of 16-45 thousand rupee per month. Only $29 \%$ of the respondents belongs to lowest income range of 5-25 thousands rupee and highest income range of more than 56 thousand rupee is $17 \%$.

Thus, we may conclude that most of the respondents are private employee as well as students and majority of the respondents belongs to the age group of 26-50 years. Most of the respondents belong to the middle income group. Majority of the respondents have business and finance education.

Now we address the question whether the level of customer satisfaction depends on the above mentioned demographic factors. For this purpose we apply Propensity Score Matching (PSM) technique. The results of PSM are given in Table 4.

Table 4. Propensity score matching

\begin{tabular}{|c|c|c|c|c|c|c|}
\hline \multirow[b]{2}{*}{ Factors } & \multicolumn{3}{|c|}{ Conventional Insurance } & \multicolumn{3}{|c|}{ Islamic Insurance } \\
\hline & Expectation & Perception & Service Quality & Expectation & Perception & Service Quality \\
\hline Non-Life insurance & 4.58 & 3.93 & 0.65 & 4.48 & 3.88 & 0.61 \\
\hline Life insurance & 4.70 & 3.89 & 0.81 & 4.57 & 3.89 & 0.68 \\
\hline Under graduate & 4.61 & 3.85 & 0.76 & 4.44 & 3.83 & 0.62 \\
\hline Graduate & 4.63 & 3.93 & 0.70 & 4.55 & 3.90 & 0.65 \\
\hline Finance education & 4.72 & 3.89 & 0.83 & 4.45 & 3.88 & 0.57 \\
\hline Medical education & 4.28 & 4.27 & 0.01 & 4.44 & 3.99 & 0.45 \\
\hline Engineer education & 4.59 & 3.83 & 0.76 & 4.26 & 4.25 & 0.01 \\
\hline Arts education & 4.58 & 3.85 & 0.73 & 4.63 & 3.96 & 0.67 \\
\hline Income up to 35 & 4.78 & 3.79 & 0.99 & 4.53 & 3.85 & 0.67 \\
\hline Income $>35$ & 4.46 & 4.04 & 0.42 & 4.54 & 3.94 & 0.60 \\
\hline Students & 4.82 & 3.82 & 1.00 & 4.48 & 3.70 & 0.78 \\
\hline Private employee & 4.61 & 3.85 & 0.76 & 4.67 & 4.07 & 0.60 \\
\hline Govt. employee & 4.66 & 4.19 & 0.47 & 4.43 & 3.96 & 0.47 \\
\hline Self employed & 4.49 & 4.07 & 0.42 & 4.37 & 3.74 & 0.63 \\
\hline Age $<35$ & 4.78 & 3.76 & 1.02 & 4.48 & 3.85 & 0.63 \\
\hline Age $>35$ & 4.54 & 4.01 & 0.53 & 4.65 & 3.96 & 0.69 \\
\hline
\end{tabular}

Likert scale varies from 1 to $5 ; 1$ means 'strongly disagree' and 5 means 'strongly agree'.

With respect to life insurance customers of Islamic insurance are more satisfied than the customers of conventional insurance. However, in case of non-life insurance and level of education no visible difference of customer satisfaction can be ascertained between both types of insurance companies.

By considering education in business and finance customers of Islamic insurance companies are relatively more satisfied than the customers of conventional insurance companies. Respondents having medical and engineering education have different responses on service quality of conventional and Islamic insurance companies. 
Respondents having medical education are more satisfied with conventional insurance companies as compared to the respondents of Islamic insurance companies. Conversely, respondents of Islamic insurance companies having engineering education are more satisfied than the respondents of conventional insurance companies. However, these results cannot be considered as significant due to low level of frequency of relevant respondents.

The respondents whose income level is less than 35 thousands rupee per month are more satisfied with Islamic insurance companies than their counterparts. Conversely, the respondents whose income level is more than 35 thousands rupee per month are more satisfied with conventional insurance companies than their counterparts.

By considering profession of the respondents students and private employee are more satisfied with Islamic insurance companies, while self-employed are more satisfied with conventional insurance companies.

In case of age factor young people are relatively more un-satisfied with conventional insurance companies and people with mature age are more un-satisfied with Islamic insurance companies.

In short, people in mature age, having monthly income of more than 35, 000 Rupee and self-employed are more satisfied with the conventional insurance companies, whereas young people and students with income level less than 35000 Rupee per month, having education in business and finance and private employee are more satisfied with the Islamic insurance companies.

\subsection{Analysis of Overall Industry on Customers' Expectation}

The results of analysis of entire industry (conventional and Islamic insurance) are given in Table 5. The results depict that the expectation of reliability which is the first construct for customer satisfaction of this questionnaire, has average value of 4.58 which reflects that respondents' demand on reliability is between 'strongly agree' and 'agree'. It is bit more toward 'strongly agree'. In this construct respondents were highly demanding on fourth variable, i.e., 'the company should perform the services at first possible instance'. Second construct is responsiveness with mean value of 4.57. It is also in between 'strongly agree' and 'agree'. Respondents' demand in this construct is higher than the demand in the first construct. In this construct respondents' demand on first and second variable is highest, i.e. 'company's employee should provide prompt services and should always willing to help customers'.

The average of third construct is at 4.55 which is empathy. It means respondents' demand on this construct is equal to the demand for responsiveness. In this construct the demand on first variable is highest, i.e. 'company should provide individual services to its customers'.

Fourth construct is convenience. Its average is at 4.60. It means respondents are between 'strongly agree' and 'agree' on convenience. In this construct respondent are more demanding on first and fifth variable. In other words, the customers are demanding more that the company should provide priority services to elderly and disable persons, give adequate guidance and information to use insurance services and ascertain prompt and hassle free settlement of claims.

Table 5. Overall insurance industry on customer satisfaction

\begin{tabular}{|c|c|c|c|}
\hline Variables & $\mathrm{E}^{*}$ & P* & Gap \\
\hline \multicolumn{4}{|l|}{ Reliability } \\
\hline My Takaful/Insurance company has trustworthy, confidant and honest staff.(Rel1) & 4.59 & 4.24 & 0.35 \\
\hline My Takaful/Insurance company is providing the service at promised time.(Rel2) & 4.56 & 3.97 & 0.59 \\
\hline My Takaful/Insurance company takes sincere interest in solving problems.(Rel3) & 4.58 & 3.89 & 0.69 \\
\hline My Takaful/Insurance company performs the service at first possible instance.(Rel4) & 4.62 & 3.84 & 0.78 \\
\hline My Takaful/Insurance company keeps error free record under intimation to me.(Re15) & 4.53 & 3.85 & 0.68 \\
\hline My Takaful/Insurance company informs me precisely as to when services will be performed.(Rel6) & 4.58 & 3.82 & 0.76 \\
\hline Overall Mean & 4.58 & 3.94 & 0.64 \\
\hline Significance & 0 & 0 & \\
\hline \multicolumn{4}{|l|}{ Responsiveness } \\
\hline Employees of my Takaful/Insurance company provide prompt service to customers.(Res1) & 4.61 & 3.97 & 0.64 \\
\hline Employees of my Takaful/Insurance company are always willing to help customers.(Res2) & 4.61 & 3.89 & 0.73 \\
\hline Employees of my Takaful/Insurance company do not ask me to unnecessarily wait for long time.(PRes3) & 4.6 & 3.88 & 0.72 \\
\hline Employees of my Takaful/Insurance company provide necessary information on services to customers.(Res4) & 4.54 & 3.93 & 0.61 \\
\hline Employees of my Takaful/Insurance company facilitate me through mobile phone/internet communications.(Res5) & 4.46 & 3.76 & 0.7 \\
\hline Overall Mean & 4.57 & 3.89 & 0.68 \\
\hline Significance & 0 & 0 & \\
\hline \multicolumn{4}{|l|}{ Empathy } \\
\hline Employees of my Takaful/Insurance company give Individual attention to customers.(Emp1) & 4.61 & 4.04 & 0.56 \\
\hline Employees of my Takaful/Insurance company keep customers' best interest at heart.(Emp2) & 4.55 & 3.83 & 0.72 \\
\hline Employees of my Takaful/Insurance company keep customers informed about their service and & 4.51 & 3.84 & 0.67 \\
\hline Employees of my Takaful/Insurance company understand customers' specific needs.(Emp4) & 4.52 & 3.82 & 0.7 \\
\hline
\end{tabular}




\begin{tabular}{|c|c|c|c|}
\hline Overall Mean & 4.55 & 3.89 & 0.66 \\
\hline Significance & 0 & 0 & \\
\hline \multicolumn{4}{|l|}{ Convenience } \\
\hline My Takaful/Insurance company provides priority services to elderly/disable persons.(con.1) & 4.65 & 3.84 & 0.81 \\
\hline My Takaful/Insurance company gives adequate information on usage of insurance' services \& facilities.(con.2) & 4.54 & 3.87 & 0.67 \\
\hline My Takaful/Insurance company gives prompt and hassle free claims' settlement.(con.3) & 4.53 & 3.74 & 0.79 \\
\hline My Takaful/Insurance company has accessible location of the branch.(con.4) & 4.56 & 3.84 & 0.72 \\
\hline My Takaful/Insurance company has operating hours convenient to its customers.(con.5) & 4.74 & 4.14 & 0.6 \\
\hline Overall Mean & 4.6 & 3.89 & 0.72 \\
\hline Significance & 0 & 0 & \\
\hline \multicolumn{4}{|l|}{ Compliance } \\
\hline Takaful companies are operating on Islamic principles.(com.1) & 4.88 & 3.92 & 0.96 \\
\hline No interest is involved in the transactions made by Takaful companies.(com.2) & 4.85 & 3.92 & 0.93 \\
\hline No uncertainty(Gharar) is involved in the transactions made by Takaful companies.(com.3) & 4.73 & 3.87 & 0.86 \\
\hline Gambling is not involve in the transactions of investment made by Takaful companies.(com.4) & 4.84 & 3.97 & 0.87 \\
\hline Overall Mean & 4.82 & 3.92 & 0.91 \\
\hline Significance & 0 & 0 & \\
\hline Overall Service Quality & 4.62 & 3.92 & 0.7 \\
\hline Significance & 0 & & \\
\hline
\end{tabular}

$* \mathrm{E}=$ Expectation, $\mathrm{P}=$ Perception.

The respondents are highly demanding on convenient hour and location of branch. Next one is compliance, i.e., adoption of Sharī'ah rules by Islamic insurance companies. The average of this construct is 4.82 , which is near to 'strongly agree'. It means respondents are strongly demanding the Sharī'ah compliance from Islamic insurance companies. It might be due to the demand of Sharī'ah compliant products in Pakistan.

Mean of the expectations of reliability, responsiveness, empathy and convenience is 4.62 which is in between 'strongly agree' and 'agree'. Respondents' expectation on all constructs is more or less equal to one, i.e., they are on near to 'strongly agree'.

\subsection{Analysis of Overall Industry on Customers' Perception}

Results in Table 5 depict that the average perception on reliability is 3.94 which is showing that respondents' response is on 'agree'. In this construct respondents' perception on first variable is high, i.e., 'company employees are trustworthy, confident and honest'. Its value is 4.24 . The value of perception on sixth variable of this construct is 3.82. It means that the customers perceive low value on keeping them informed about the services rendered by the insurance company. Second construct is responsiveness. On this construct average is 3.89 , which is in between 'agree' to 'neutral'. Respondents' perception is low in this construct. The perception on fifth variable, namely 'employees facilitate me through mobile and internet' is low as compared to other variables in this construct. Third construct is empathy. Similar to the second construct, the mean of this construct is 3.89 which lies in between 'agree' and 'neutral'. In this construct respondents are less satisfied on fourth variable as compared to others which is 'employees are able to understand customers' specific needs'. Fourth construct on convenience has respondents' average response at 3.89 which lies between 'agree' and 'neutral'. In this construct the respondents' perception on third variable is low, i.e., 'company provides prompt and hassle free claim settlement'. On fifth variable it is high which is 'operating hours are convenient to customers'. In the fifth construct average perception on compliance is 3.92 which is near to 'agree' level. It means respondents do agree that Islamic insurance companies are following the Sharī'ah rules in their decisions. Average perception on reliability, responsiveness, empathy and convenience is 3.92 which is in between 'agree' and 'neutral'. Results depict that companies need to do more efforts for increasing the perception of clients on all constructs. Perception of respondents is recorded low on all constructs but specifically on the constructs of responsiveness and convenience. Thus, companies need to do more efforts to improve the perception level of customer.

\subsection{Analysis of Overall Industry on Customers'Satisfaction}

Level of customer satisfaction depends on the overall gap between the expectation and perception of this test (Service Quality = Expectation - Perception). If the gap is high, the customers are less satisfied and vice versa. Here the result on gap, as shown in Table 5, is statistically significant. The gap is $\mathrm{E}-\mathrm{P}=0.70$. It means expectations are higher than perception. Industry still needs to improve its quality of services on different constructs (i.e., reliability, responsiveness, empathy and convenience) to increase the level of customers' satisfaction.

\subsection{Comparative Analysis of Islamic and Conventional Insurance Industries}

One of the objectives of this study is to have a comparative look at the performance of conventional and Islamic insurance industries with respect to their service quality. Hence, the study runs independent sample t-test, by 
creating two sub-samples out of our general sample.

The results of our test, as reflected in Table 6 , show that overall service quality difference between Islamic and conventional insurance industries is random, as the significance value of 0.57 renders the mean difference as insignificant. Similar is the case with various constructs of expectation and perception generally showing insignificant results.

Table 6. Comparative analysis of islamic \& conventional insurance industries

\begin{tabular}{|c|c|c|c|c|c|}
\hline \multirow{2}{*}{ Construct } & \multirow{2}{*}{ Insurance Industry } & \multicolumn{2}{|c|}{ Mean } & \multicolumn{2}{|c|}{ Significance (2T) } \\
\hline & & Expectation & Perception & Expectation & Perception \\
\hline \multirow{2}{*}{ Reliability } & Islamic & 4.58 & 3.92 & 0.96 & 0.69 \\
\hline & Conventional & 4.58 & 3.96 & 0.96 & 0.69 \\
\hline \multirow{2}{*}{ Responsiveness } & Islamic & 4.56 & 3.91 & 0.87 & 0.70 \\
\hline & Conventional & 4.57 & 3.86 & 0.86 & 0.70 \\
\hline \multirow{2}{*}{ Empathy } & Islamic & 4.48 & 3.88 & 0.05 & 1.00 \\
\hline & Conventional & 4.63 & 3.88 & 0.04 & 1.00 \\
\hline \multirow{2}{*}{ Convenience } & Islamic & 4.51 & 3.83 & 0.09 & 0.22 \\
\hline & Conventional & 4.71 & 3.96 & 0.10 & 0.21 \\
\hline \multirow{2}{*}{ Compliance } & Islamic & 4.83 & 4.23 & 0.96 & 0 \\
\hline & Conventional & 4.82 & 3.53 & 0.96 & 0 \\
\hline \multirow{2}{*}{ Overall } & Islamic & 4.53 & 3.88 & 0.17 & 0.73 \\
\hline & Conventional & 4.62 & 3.92 & 0.16 & 0.73 \\
\hline Service Quality & $\begin{array}{l}\text { Islamic } \\
\text { Conventional }\end{array}$ & \multicolumn{2}{|c|}{$\begin{array}{l}0.65 \\
0.70\end{array}$} & \multicolumn{2}{|c|}{0.57} \\
\hline
\end{tabular}

Gaps between expectation and perception in each construct of SERVQUAL for Islamic and conventional companies are given in Table 7. The results for the constructs of reliability, responsiveness, empathy and convenience, are insignificant.

However, significant difference is found in the variable of Sharì'ah compliance of Islamic insurance business. The mean of service quality gap in this construct for Islamic companies is at 0.60 and that of conventional is 1.30. It means that the customers of Islamic insurance companies consider Islamic insurance service provider at a better level of Sharì'ah compliance as compared to those of conventional insurance companies.

Table 7. Construct-wise gap analysis

\begin{tabular}{llcc}
\hline Variables & Company Type & Mean of Gap & Sig. (2T) \\
\hline \multirow{2}{*}{ Reliability } & Islamic & 0.66 & 0.75 \\
& Conventional & 0.62 & \\
Responsiveness & Islamic & 0.66 & 0.68 \\
& Conventional & 0.71 & \\
Empathy & Islamic & 0.60 & 0.21 \\
& Conventional & 0.75 & 0.66 \\
Convenience & Islamic & 0.68 & \\
& Conventional & 0.74 & 0 \\
Compliance & Islamic & 0.60 & \\
& Conventional & 1.30 & \\
\hline
\end{tabular}

To have a snap short of the above discussion under the results of independent sample $t$ test, it can be inferred that the customers of Islamic insurance companies are better informed than their counterparts about the basic concepts of Sharī'ah relevant to insurance and the Sharì'ah compatibility of their company, while with regard to all other constructs of service quality both types of customers are insignificantly different.

\subsection{Company wise Analysis on Customer Satisfaction}

In this part we compare different firms on service quality. Results and frequency of the respondents for each company are given in Table 8 .

Table 8. Company-wise analysis on customer satisfaction

\begin{tabular}{lcccc}
\hline Company Name & Frequency & Expectation & Perception & Service Quality Gap \\
\hline Askari General Insurance (C)* & 51 & 4.26 & 4.09 & 0.17 \\
Pak-Qatar General Takaful (I)* & 59 & 4.40 & 3.83 & 0.57 \\
Pak-Qatar Family Takaful (I)* & 86 & 4.60 & 3.97 & 0.63 \\
\hline
\end{tabular}




\begin{tabular}{lllll}
\hline Dawood Family Takaful (I)* & 66 & 4.50 & 3.78 & 0.72 \\
Pak-Kuwait Takaful (I)* & 16 & 4.74 & 3.97 & 0.77 \\
EFU Life (C)* & 35 & 4.83 & 3.94 & 0.88 \\
EFU General (C)* & 36 & 4.90 & 3.59 & 1.31 \\
Others (C)* & 49 & 4.63 & 3.92 & 0.70 \\
Overall Results & & 4.62 & 3.91 & 0.71 \\
\hline
\end{tabular}

* $\mathrm{C}=$ Conventional Insurance Company, I=Islamic Insurance Company.

Results show that average expectation on all constructs for Askari General Insurance and Pak-Qatar General Takaful is near to 'agree' level and for rest of the insurance companies it tends to 'strongly agree' level. However, no significant difference is observed on perception basis that tends to be at 'agree' level. The table depicts that overall Askari General Insurance is showing better results. Its gap between expectation and perception is lower as compared to all other companies. Thus, customers of Askari General Insurance are more satisfied. In Islamic insurance sector, results of Pak-Qatar General Takäful are on second place. Results depict that customers of EFU General Insurance are least satisfied as compared to the customers of other companies.

\subsection{Analysis of Preferences of Respondents for Insurance Industry}

Preference is the last part of this questionnaire. Respondents were asked about the reasons of taking the insurance policy and the extent of importance given to specific factors, i.e., high, medium, low and no importance represented by the integers 1,2,3 and 4, respectively. Results are shown in Table 9.

Table 9. Overall results on preferences (\%)

\begin{tabular}{llcccc}
\hline S. No & Preferences & High & Medium & Low & No \\
\hline 1 & Sharíah compliance & 53.6 & 20.1 & 11.2 & 15.1 \\
2 & Motivation from religion & 41.3 & 29.1 & 14.5 & 15.1 \\
3 & Interest free business & 57 & 20.1 & 12.8 & 10.1 \\
4 & Risk management & 44.7 & 43.6 & 9.5 & 2.2 \\
5 & Low cost & 40.2 & 46.9 & 9.5 & 3.4 \\
6 & Return & 29.1 & 48.6 & 12.8 & 9.5 \\
7 & Easy access & 62 & 31.8 & 1.7 & 4.5 \\
\hline
\end{tabular}

First variable of preference is Sharī'ah compliance of the insurance business. Overall $54 \%$ of respondents give high importance to the Shari'ah compliance of the business and $27 \%$ give no importance to this factor. Second preference is about the motivation from religion. $41 \%$ of respondents consider it highly important while choosing the insurance company whereas $15 \%$ do not give any importance to this factor. Third preference is interest free insurance business. $57 \%$ of respondents consider this factor highly important and $10 \%$ consider it as not important. Fourth, fifth, sixth and seventh preferences relate to risk management, low cost, return and easy access to insurance services, respectively. For all these factors $78 \%$ to $94 \%$ respondents give high to medium importance and only less than $10 \%$ respondents give no importance to these factors.

\subsection{Comparison of Conventional \& Islamic Insurance Industry on Preferences}

When we make a comparison between conventional and Islamic insurance industry on the basis of preferences as reflected in Table 10, one thing which is very important to note is that the respondents of Islamic insurance companies give more importance to Sharíah compliance factor of insurance companies as compared to the respondents of the conventional insurance companies. For example, first preference is about the Sharíah compliance of insurance business, $83 \%$ of Islamic insurance respondents consider it highly important while only $15 \%$ of the conventional insurance respondents consider it highly important. Second preference is the motivation from religion. 91\% customers of Islamic insurance consider this factor highly and medium important while $45 \%$ of the respondents of conventional insurance consider it as highly important. In case of third factor, namely insurance business to be interest free, $72 \%$ of the Islamic insurance customers consider it highly important, whereas only $37 \%$ of the customers of conventional insurance consider it as highly important.

Table 10. Conventional versus Islamic insurance on preferences (\%)

\begin{tabular}{|c|c|c|c|c|c|c|}
\hline Number & Preferences & Company & High & Medium & Low & No \\
\hline \multirow{2}{*}{1} & \multirow{2}{*}{ Sharīah compliance } & Conventional & 15.4 & 29.5 & 23.1 & 32.1 \\
\hline & & Islamic & 83 & 13 & 2 & 2 \\
\hline \multirow{2}{*}{2} & Motivation from & Conventional & 19.2 & 24.4 & 24.4 & 32.1 \\
\hline & religion & Islamic & 58 & 33 & 7 & 2 \\
\hline
\end{tabular}




\begin{tabular}{|c|c|c|c|c|c|c|}
\hline \multirow{2}{*}{3} & Business to be interest & Conventional & 37.2 & 21.8 & 20.5 & 20.5 \\
\hline & free & Islamic & 72 & 19 & 7 & 2 \\
\hline \multirow{2}{*}{4} & \multirow{2}{*}{ Risk management } & Conventional & 42.3 & 44.9 & 11.5 & 1.3 \\
\hline & & Islamic & 46 & 43 & 8 & 3 \\
\hline \multirow{2}{*}{5} & \multirow{2}{*}{ Low cost } & Conventional & 37.2 & 50 & 11.5 & 1.3 \\
\hline & & Islamic & 43 & 44 & 8 & 5 \\
\hline \multirow{2}{*}{6} & \multirow{2}{*}{ Return } & Conventional & 20.5 & 53.8 & 15.4 & 10.3 \\
\hline & & Islamic & 36 & 44 & 11 & 9 \\
\hline \multirow{2}{*}{7} & \multirow{2}{*}{ Easy access } & Conventional & 62.8 & 34.6 & 1.3 & 1.3 \\
\hline & & Islamic & 61 & 30 & 2 & 7 \\
\hline
\end{tabular}

As far as risk management, low cost, return and easy access to insurance services are concerned the ratios of the respondents of both types of companies are similar. $74 \%$ to $97 \%$ of respondents give medium to high importance and only less than $10 \%$ respondents give no importance to these factors.

\section{Conclusions and Recommendations}

Results on service quality indicate that overall insurance industry gap between expectation and perception is significant, i.e., expectation is higher than perception. The gap is visible on all constructs of service quality.

Results also depict that insignificant difference is found on service quality between conventional and Islamic insurance companies on the constructs of reliability, responsiveness, empathy and convenience. However, significant difference is found on the construct of Sharíah compliance between conventional and Islamic insurance companies. Respondents of Islamic insurance companies are more concerned to Sharíah compliance as compared to their conventional counterparts.

This study suggests a significant improvement in the service quality and efficiency of conventional and Islamic insurance industry of Pakistan. In this regard both types of insurance companies have to focus on effective risk management, low cost of insurance, hassle free settlement of claims and easy access to insurance services. Particularly, the conventional insurance companies need to focus on young people, private employees and lower income groups, whereas the Islamic insurance companies have to put more efforts to improve Sharīah compliance and to attract self-employed and higher income groups.

\section{References}

Ahmad, A., Kashif, R., \& Safwan, I. S. (2010). An empirical investigation of Islamic banking in Pakistan based on perception of service quality. African Journal of Business Management, 4(6), 1185-1193.

Awan, H., Bukhari, K. S., \& Iqbal, A. (2011). Service quality and customer satisfaction in the banking sector: A comparative study of conventional and Islamic banks in Pakistan. Journal of Islamic Marketing, 2(3), 203224. http://dx.doi.org/10.1108/17590831111164750

Bhargavi, K. R., \& Kumar, A. (2010). Influence of service quality on banking customers' behavioural intentions. International Journal of Economics and Finance, 2, 18-28.

Chong, C. M. A., Kumar, M., \& Fong, T. K. (2011). Measuring service quality of conventional and Islamic banks: A comparative analysis. International Journal of Quality \& Reliability Management.

Cronin, J., \& Taylor, S. (1992). Measuring service quality: A re-examination and extension. Journal of Marketing, 56(3), 55-68. http://dx.doi.org/10.2307/1252296

Evangelos, E., \& Rand, G. K. (2006). Path analysis of perceived service quality, satisfaction and loyalty in Greek insurance (pp. 501-519). Emerald Group Publishing Limited.

Ghobadian, A., Speller, S., \& Jones, M. (1994). Service quality concepts and models. International Journal of Quality \& Reliability Management, 11(9), 43-66. http://dx.doi.org/10.1108/02656719410074297

Government of Pakistan. (2006, 2009, 2010 \& 2011). Economic Survey of Pakistan.

Hamid, F. S. (2011). Measuring Service Quality in The Takäful Industry (pp. 118-124). SEGi Review ISSN 1985-5672.

Jayaraman, M. S. C. (2010). Service quality delivery and its impact on customer satisfaction in Malaysia.

Khalid, S., Mahmood, B., Abbas, M., \& Hussain, S. (2011). Customer satisfaction with service quality in conventional banking in Pakistan: The case of faisalabad. International Journal of Marketing Studies, 3(4), 165-174. http://dx.doi.org/10.5539/ijms.v3n4p165

Khan, A. (2013). Islamic insurance in theory and practice: A critical appraisal. International Institute of Islamic 
Economics, IIU Islamabad, Unpublished $\mathrm{PhD}$ Dissertation,

Kotler, P., \& Keller, K. (2006). Marketing management (12th ed.). Prentice Hall.

Kumar, M., Kee, F. T., \& Charles, V. (2009). Comparative evaluation of critical factors in delivering service quality of banks. International Journal of Quality \& Reliability Management, 351-377.

Ladhari, R. (2009). A review of twenty years of SERVQUAL research. International Journal of Quality and Service Sciences, 172-198

Ladhari, R., Ladhari, I., \& Morales, M. (2011) Bank service quality: Comparing Canadian and Tunisian customer perceptions. International Journal of Bank Marketing, 29(3), 224-246. http://dx.doi.org/10.1108/02652321111117502

Leo, M. H. (2009). Customer perception on service quality in retail banking in Middle East. International Journal of Islamic and Middle Eastern Finance and Management.

Lian, T. K., \& Aziz, F. A. (2006). Retrieved Decemer 18, 2011, from http://www.Takāful.coop/index.php?option=com_content\&view=article\&id=73\&Itemid=55

Naeem, H., Akram, A., \& Saif, M. I. (2009). Service quality and its impact on customer satisfaction: An empirical evidence from the Pakistani banking sector. International Business \& Economics Research Journal, 8(12), 99-104.

Noreen, U. (2009). Cost efficiency and total factor productivity: An empirical analysis of insurance sector. MS Thesis, IIU Islamabad.

Osman, I., Ali, H., \& Rashid, A. Z. (2009). Customers satisfaction in Malaysian islamic banking. International Journal of Economics and Finance, 1(1), 197-202.

Othman, A. Q., \& Lynn, O. (2001). Adopting and measuring customer Service Quality (SQ) in Islamic banks: A case study in Kuwait finance house. International Journal of Islamic Financial Services, 3(1).

Parasuraman, A., Valarie, Z., \& Leonard, B. (1994). Reassessment of expectations as a comparison standard in measuring service quality: Implications for further research. Journal of Marketing, 58(January), 111-124. http://dx.doi.org/10.2307/1252255

Parasuraman, A., Zeithamal, V. A., \& Berry, L. L. (1988). SERVQUAL: A multiple item scale for measuring customer perception of service quality. Journal of Retailing, 64(1), 12-40.

Parasuraman, A., Zeithmal, V., \& Berry, L. (1985). A conceptual model of service quality and its implications for future research. Journal of Marketing, 49(4), 41-50. http://dx.doi.org/10.2307/1251430

Ramdhani, 1. A., \& Kurniati, A. R. (2011). The influence of service quality toward customer satisfaction of Islamic Sharia bank. Australian Journal of Basic and Applied Sciences, 1099-1104.

Sadeghi, T., \& Farokhian, S. (2011). The determination of the Critical Success Factors (CSFs) in insurance services in Iran. Asian Journal of Business Management Studies, 4-6.

Şafakli, \& Veli, O. (2007). Testing SERVQUAL dimensions on the commercial bank sector of northern cyprus. Financial Theory \& Practice, 31(2), 185-201.

SECP. (2013). Retrieved from http://www.secp.gov.pk/ID/id_registeredentities.asp

Shafie, S., Azmi, D. W., \& Haron, P. S. (2004). Adopting and measuring customer service quality in Islamic Banks: A case study of bank Islam Malaysia berhad. Journal of Muamalat and Islamic Finance Research, $1(1)$.

Shahid, H., Rehman, R., \& Raoof, G. S. (2010). Efficiencies comparison of islamic and conventional banks of Pakistan. International Research Journal of Finance and Economics, 24-42.

Sharma, R. K., \& Bansal, M. R. (2011). Service quality assessment in insurance sector: A comparative study between Indian and Chinese customers. Research Journal of Finance and Accounting, 2(5), 1-17.

Shemwell, D. J., Yavas, U., \& Bilgin, Z. (1998). Customer-service privider relationship: An empirical test of a model of service quality, satisfaction and relationship oriented outcome. Internationl Jouranl of Service Industry Management, 9, 155-168. http://dx.doi.org/10.1108/09564239810210505

Siddiqui, D. M., \& Sharma, T. G. (2010). Measuring the customer perceived service quality for life insurance services: An empirical investigation. International Business Research, 171-186.

Slamet, W., \& Soviyanti, E. (2007). Adapting Islamic banks CARTER model: An empirical study in Riau's 
Syariah Banks, Indonesia. Proceeding PESAT (Psikologi, Sastra, Arsitek \& Sipil) Auditorium Kampus Gunadarma, 120-127.

Spreng, R. A., \& Mackoy, R. D. (1996). An empirical examination of a model of perceived serivice quality and satisfaction. Journal of Retailling, 72, 201-14. http://dx.doi.org/10.1016/S0022-4359(96)90014-7

State Bank of Pakistan. (2006, 2009, 2010 \& 2011). Financial stability review.

Sungip, A. A. (2008). An assessment on service quality in Malaysia insurance industry. IBIMA, 14.

Sureshchandar, G., Rajendran, C., \& Anantharaman, R. (2001). The relationship between service quality and customer satisfaction - a factor specific approach. Journal of Services Marketing, 363-379.

Taap, M. A., Chong, S. C., Kumar, M., \& Fong, T. K. (2011). Measuring service quality of conventional and Islamic banks: A comparative analysis. International Journal of Quality \& Reliability Management, 822 840. http://dx.doi.org/10.1108/02656711111162505

Tahir, M. D. I., Bakar, N., Ismail, M., \& Wan, W. Z. (2006). Customer expectations and perceptions of service quality in islamic banking: Evidence from Malaysia.

Uma, S. M., Bibhuti, B. M., Saroj, K. B., \& Bidhu, B. M. (2010). Employee evaluations of customer satisfaction: A comparative study between public and private banks in India. International Research Journal of Finance and Economics, 134-144.

Upadhyaya, D., \& Badlani, M. (2011). Service quality perception and customer satisfaction in life insurance. International Conference on Technology and Business Management.

Wahab, A. R., Lewis, M. K., \& Hassan, M. K. (2007). Islamic Takāful: Business models, sharîtah concerns, and proposed solutions. Thunderbird International Business Review, 371-396. http://dx.doi.org/10.1002/tie.20148

\section{Note}

Note 1. In Mudārabah model policyholder and insurance operator are considered as investors, the former invest with capital and the later with labor and the compensations are settled on profit/loss basis. In Wakälah model policyholder acts as principal and the insurance operator as agent. The former is paid on profit/loss basis and the later is paid for his services. In wakälah and mudärabah models $100 \%$ surplus (net profit) is owned by the policyholders. In Waqf-Wakälah model investors create insurance company in the form of an endowment fund through donations and insurance operator acts as agent of endowment (principal). Policyholders also donate to endowment fund for the purpose of hedging their risk. The investors as shareholders and policyholders can invest together with the endowment on the basis of profit and loss sharing. After deduction of profit to the shareholders and agent as well as other expenses and taxes $100 \%$ of the surplus (net profit) is owned by the endowment fund which can be donated to the participants. In the opinion of authors the concept of giving donations for the purpose of hedging only donator's risk as well as the distribution of 'investment income' among investors and agent through 'endowment fund' need to be justified on legal and Islamic principles.

\section{Copyrights}

Copyright for this article is retained by the author(s), with first publication rights granted to the journal.

This is an open-access article distributed under the terms and conditions of the Creative Commons Attribution license (http://creativecommons.org/licenses/by/3.0/). 